\title{
Corticotropin releasing hormone in colonic mucosa in patients with ulcerative colitis
} Y Kawahito, H Sano, S Mukai, K Asai, S Kimura, Y Yamamura, H Kato, G P Chrousos,
R L Wilder, M Kondo

\begin{abstract}
Corticotropin releasing hormone (CRH) is a key hormone in integrated response to stress, acting as the major regulator of the hypothalamic-pituitary-adrenal axis. Recently, local production of CRH has been detected in normal human colonic enterochromaffin cells. CRH is locally secreted in granulomatous and arthritic tissues in rats and humans, where it seems to act as a local proinflammatory agent. To find out if CRH is present in colonic tissues of patients with ulcerative colitis, this study examined the expression of this peptide in the large bowel of patients with ulcerative colitis. Colonic tissues of patients with ulcerative colitis obtained by endoscopic biopsy were immunostained with anti-CRH antibody. CRH messenger (m) RNA was also examined in biopsy specimens of ulcerative colitis by the reverse transcribed polymerase chain reaction method and by in situ hybridisation. Considerably enhanced expression of immunoreactive CRH was found in mucosal inflammatory cells. Intense staining with anti-CRH antibody was also shown in mucosal macrophages. CRH mRNA was expressed in mucosal epithelial cells. The expression of immunoreactive CRH in colonic mucosal epithelial cells of ulcerative colitis slightly increased, but not significantly, compared with normal colonic mucosal epithelial cells. These results suggest that CRH may play a part in the modulation of intestinal immune and inflammatory system, and as a modulator in the pathogenesis of ulcerative colitis.

(Gut 1995; 37: 544-551)
\end{abstract}

Keywords: corticotropin releasing hormone, ulcerative colitis, colonic mucosa immunohistochemistry, polymerase chain reaction, in situ hybridisation.

Corticotropin releasing hormone (CRH), a 41amino acid hypothalamic peptide, ${ }^{1}$ is a major regulator of the stress response and of the immune/inflammatory reaction. ${ }^{2-7}$ In the central nervous system, CRH stimulates several stress related behaviours, as well as the pituitary production of adrenocorticotropin releasing hormone (ACTH), which in turn stimulates the production of glucocorticoids by the adrenal cortex. ${ }^{8}$ The adrenal cortex exerts indirectly anti-inflammatory and immunosuppressive effects. Immunoreactive $\mathrm{CRH}$ and CRH messenger (m) RNA are also present in cells of the immune system and peripheral tissues outside the brain, such as the spinal cord, adrenal medulla, lung, liver, ${ }^{9}$ pancreas, ${ }^{10}$ placenta, ${ }^{11}$ and ovary. ${ }^{12}$ Recent in vitro findings support that CRH have several immunomodulatory roles, such as the secretion of cytokines (interleukin (IL)-1, IL-2, and IL-6), ${ }^{13} 14$ stimulation of lymphocyte proliferation and expression of IL-2 receptor, ${ }^{15}$ enhancement of natural killer cell mediated lysis, ${ }^{16}$ and secretion of leucocyte derived ACTH and $\beta$-endorphin. ${ }^{17}$

Some studies have previously shown that CRH is locally secreted in inflammatory sites of several animal models and arthritic joints of patients with rheumatoid arthritis. ${ }^{18-20}$ The extent and intensity of immunoreactive $\mathrm{CRH}$ in inflammatory sites correlated to the extent and intensity of mononuclear cell infiltration. In the carrageenin mediated inflammation, immunoneutralisation of $\mathrm{CRH}$ resulted in a significant decrease in the volume and cellularity of the inflammatory exudate. ${ }^{18}$ These findings suggest that $\mathrm{CRH}$ has predominantly proinflammatory effects in peripheral inflammatory sites.

The presence of several neuropeptides such as substance $\mathrm{P}^{21}$ and vasoactive intestinal peptide $^{22}$ have been reported in the gut. These peptides have a role in the pathogenesis of inflammatory bowel disease ${ }^{23}$ as well as several gastrointestinal functions, such as digestion, gastrointestinal motility, secretion of gastric acid, and immunomodulation of the activity of gut associated lymphoid tissues. ${ }^{24-29}$ Recently; we found that $\mathrm{CRH}$ was locally secreted by enterochromaffin cells in human colon, ${ }^{30}$ but the function of this neuropeptide in colonic mucosa is still unclear. In this study, we investigated the role of $\mathrm{CRH}$ in the pathogenesis of ulcerative colitis. To accomplish this, we examined colonic mucosa from patients with ulcerative colitis, and compared them with those of normal subjects by immunohistochemical $\mathrm{CRH}$ staining, and $\mathrm{CRH}$ mRNA detection by reverse transcribed polymerase chain reaction (PCR) method and by in situ hybridisation.

\section{Methods}

\section{Tissues specimens}

Colonic mucosal samples were obtained from endoscopic biopsy specimens of 10 patients with ulcerative colitis (male: 5 , female: 5 , age: 21-36 years). The diagnosis of ulcerative colitis was based on history and clinical examination, endoscopic examination, and pathological 
findings of ulcerative colitis. Three patients had pancolitis, five patients had left sided colitis, and two patients had proctitis. All patients were receiving no treatment at the onset of disease. Four specimens were obtained from ascending colon, one from transverse colon, two from descending colon, eight from sigmoid colon, nine from rectum. The control group, which underwent total colonoscopy to exclude polyps (male: 6, female: 4, ages: 20-76 years) had normal physical and endoscopic examination, and these biopsy specimens were diagnosed as normal tissues with haematoxylin and eosin stain. In the control group, two specimens were obtained from ascending colon, two from transverse colon, one from descending colon, three from sigmoid colon, two from rectum. All patients were prepared with oral polyethyleneglycol lavage solutions but no enema, to decrease mechanical stimulation of colon.

\section{$R N A$ preparation and analysis}

Biopsy specimens of colonic mucosa from 10 patients with ulcerative colitis and from 10 normal subjects were obtained for RNA analysis. Total RNA was collected from three biopsy specimens of each person. Total cellular RNA was extracted by the acid guanidium thiocyanate-phenol-chloroform method. ${ }^{31}$ For PCR analysis of RNA CDNA was prepared by reverse transcription of $10 \mu \mathrm{g}$ of each RNA sample using the GeneAmp RNA PCR kit (PerkinElmer Cetus Instruments, Norwalk, CT, USA) with random hexamer primers. ${ }^{19}$ The cDNA was diluted to $100 \mu l$ and the same mixtures were used in all PCR reactions. PCR reactions were performed in a $50 \mu$ l reaction volume containing $5 \mu$ l of each cDNA in $50 \mathrm{mM} \mathrm{KCl}, 10$ $\mathrm{mM}$ TRIS-HCl (pH 8.3), $2 \mathrm{mM} \mathrm{MgCl}_{2}, 200$ $\mu M$ each of dATP, dCTP, dGTP, and dTTP, $2 \mathrm{ng} / \mu \mathrm{l}$ each of the sense and antisense primers, a 5 units of Taq polymerase (Perkin-Elmer Cetus). The primers used were: (a) human $\mathrm{CRH},{ }^{20}$ sense 5'-CAATCGAGCTGTCAAGAGAGC-3' and antisense 5'-GGAAGAAATCCAAGGGCTGAG-3', (b) $\beta$-actin, sense 5'-GTGGGGCGCCCCAGGCACCA$3^{\prime}$, and antisense 5'-CTTTAGCACGCACTGTAATTCCTC-3'. All primer pairs amplified a fragment that crossed an intron, thereby distinguishing by the size of the expected fragment after amplification between cDNA and contaminating genomic DNA. The conditions for thermal cycling were: $94^{\circ} \mathrm{C}$ for one minute, $55^{\circ} \mathrm{C}$ for two minutes, and $72^{\circ} \mathrm{C}$ for three minutes for 50 cycles. This programme was preceded by five minutes at the given denaturation temperature and followed by seven minutes at $72^{\circ} \mathrm{C}$. The amplification reactions were analysed on $3.0 \%$ agarose gels.

\section{Antibodies}

Rabbit polyclonal anti-CRH antibody was affinity purified by absorption to and elusion from a CRH-conjugated sepharose 4B (Pharmacia Fine Chemical, Uppsala, Sweden) column. ${ }^{18} 19$ Characteristics of this antibody used was: titre, $1: 96000$; dilution that causes $10 \%$ displace- ment of radiolabelled tracer, effective dose ${ }_{90} 40$ $\mathrm{pg} / \mathrm{ml}$; concentration that causes $50 \%$ displacement of radiolabelled tracer, effective dose $_{50}$ $170 \mathrm{pg} / \mathrm{ml}$. The anti-CRH antiserum has cross reactivity of less than $0.001 \%$ for growth hormone releasing hormone, luteinising hormone releasing hormone, antidiuretic hormone, ACTH, luteinising hormone, follicle stimulating hormone, thyroid stimulating hormone, prolactin, $\beta$-endorphin, and growth hormone.

Antihuman pan-macrophage antibody (KiM1) ${ }^{32}$ for double antibody immunostaining was purchased from Seikagaku Corporation, Tokyo, Japan. This antibody was secreted by a hybridoma formed from the fusion of mouse myeloma cells from BALB/C mouse immunised against human macrophages.

\section{Immunohistochemistry}

Tissue immunohistochemical staining was done with the Vectastain avidin-biotin peroxidase complex kit (Vector Laboratories, Burlingame, CA, USA). Colonic tissue specimens from 10 ulcerative colitis patients and 10 control subjects were preserved in $10 \%$ formalin. Specimens were embedded in paraffin wax, serially sectioned onto microscope slides at a thickness of $4 \mu \mathrm{m}$, and then deparaffinised. The slides were immersed for 45 minutes in $0.3 \%$ hydrogen peroxide in methanol to deplete endogenous peroxidase. Non-specific binding sites were saturated with $0.3 \%$ bovine serum albumin, normal goat serum diluted to 1:66.7 in phosphate buffered saline for 20 minutes. Primary antibodies against $\mathrm{CRH}$ (affinity purified anti-CRH immunoglobulin $\mathrm{G}$ (IgG), $30 \mu \mathrm{g} / \mathrm{ml}$ ), or control normal rabbit IgG (Vector) applied to tissue sections and incubated in a humidified chamber at a room temperature for 30 minutes. The sections were then washed with phosphate buffered saline for 10 minutes. Biotinylated goat antirabbit IgG (Vector) in $10 \mathrm{ml}$ of phosphate buffered saline were applied to tissue sections, and the slides were incubated at room temperature for 30 minutes. They were further washed with phosphate buffered saline for 10 minutes. This was followed by incubation with performed avidin DH-biotinylated peroxidase (Vector) for 45 minutes, and followed by phosphate buffered saline for 10 minutes. Finally, colour was developed by immersion of the sections in a peroxidase substrate solution $\left(0.05 \% 3,3^{\prime}-\right.$ diaminobenzidine tetrahydrochloride, $0.04 \%$ nickel chloride, and $0.01 \%$ hydrogen peroxide in $0.05 \mathrm{M}$ TRIS-HCl ( $\mathrm{pH} \mathrm{7.2))} \mathrm{for} \mathrm{two} \mathrm{to} \mathrm{five}$ minutes. The sections were counterstained with $0.5 \%$ light green (Sigma Chemical, St Louis, MO, USA). Positive staining was shown by brownish-black deposits, and background staining was light green.

For each of the tissue specimens, the extent and intensity of staining with anti-CRH antibody in mucosal inflammatory cells were graded on a scale of $0-4+$ by two blinded observers on two separate occasions using coded slides as previously described. ${ }^{19} 20$ A 4+ grade implies maximally intense staining, whereas 0 implies no staining. Analysis of data 


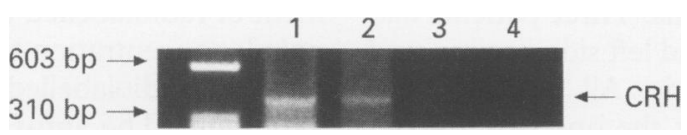

Figure 1: Polymerase chain reaction (PCR) analysis of reverse transcribed $R N A$ isolated from colonic mucosa. Total RNA $(20 \mu \mathrm{g})$ was purified from 10 normal subjects and 10 patients with ulcerative colitis, and collected from three biopsy specimens of each person. Primers for $\mathrm{CRH}$ generated the expected 425 nucleotide band after 50 cycles of PCR. Negative control reactions performed with no $R N A$ added to the reverse transcribed reaction or no reverse transcriptase yielded no detectable bands. Lane 1; normal colonic mucosa, lane 2; colonic mucosa from a patient with ulcerative colitis, lane 3; no $R N A$, lane 4; normal subject with no reverse transcriptase.

was performed using the Mann-Whitney U test.

\section{Double antibody immunostaining}

Double antibody immunostaining was done with the Vectastain avidin-biotin peroxidase complex kit (Vector) using the manufacturer's suggested protocol and reagents. ${ }^{30} 33$ The same tissues for the same block were stained with antimacrophage antibody (Seikagaku) diluted to $1: 100$ in phosphate buffered saline using the alkaline phosphatase method and with anti-CRH antibody $(30 \mu \mathrm{g} / \mathrm{ml})$ using the peroxidase method. Control staining was done with BALB/C ascites fluid (Cendarlane, Ontario, Canada) or normal rabbit IgG (Vector). Counterstaining was done with $0.5 \%$ light green. Positive staining was shown by brownish-black deposits for the peroxidase method, red deposits for the alkaline phosphatase method, and black-red deposits for the double antibody staining.

\section{Oligonucleotide probe}

We used an oligonucleotide probe to detect specific nucleotide sequences of CRH mRNA. This probe (5'-GAGAGCCGCGGGGCTGTCGAGCGAGCGCCGAGGCAGCAGCAGCTGCT-3') was made by a DNA synthesiser (Applied Biosystems, Foster City, CA, USA) and was complementary to a region between nucleotides 1668 and 1714 of the human $\mathrm{CRH}$ gene. ${ }^{34}$ This region had $79 \%$ nucleotide sequence homology to nucleotides 898-999 of the rat CRH mRNA. The oligonucleotide was labelled at the $3^{\prime}$ end with $\alpha{ }^{32} \mathrm{P}-$ dCTP (ICN, Tokyo, Japan) using terminal transferase (GIBCO BRL, Gaithersburg, MD, USA).

\section{In situ hybridisation and autoradiography}

We analysed CRH mRNA by in situ hybridisation in biopsy specimens from three ulcerative colitis patients and three normal subjects. In ulcerative colitis patients, one specimen was obtained from ascending colon, one from descending colon, one from sigmoid colon, two from rectum. In normal subjects, one specimen was obtained from ascending colon, one from transverse colon, one from descending colon, one from sigmoid colon, one from rectum. In situ hybridisation was performed as described previously by us. ${ }^{30}$ Colonic tissue sections were embedded in paraffin wax and placed onto gelatin coated slides at a thickness of $4 \mu \mathrm{m}$. The slides were then acetylated, rinsed in phosphate buffered saline, dehydrated in graded solutions of ethanol, and dried before hybridisation. Hybridisation was performed for 24 hours at $37^{\circ} \mathrm{C}$ using $1 \times 10^{6}$ $\mathrm{cpm}$ of ${ }^{32} \mathrm{P}$-labelled oligonucleotide probe. The slides were washed for one hour at $55^{\circ} \mathrm{C}$ in $0.2 \times$ standard saline citrate. After further washing, the slides were dehydrated in graded solutions of ethanol, air dried, and dipped into photographic emulsion. After exposure for 14 days at $4^{\circ} \mathrm{C}$, the slides were developed in Kodak D 19 developer (Kodak, Rochester, NY, USA) for three minutes, rinsed in water, and fixed in Fixer Naniwa Photochemical Supplies, Osaka, Japan) for three minutes. The slides were finally counterstained with haematoxylin. Tissue sections were incubated with RNase buffer containing $0.5 \% \mathrm{NaCl}, 10 \mathrm{~m}$ TRIS-HCl buffer (pH 8.0, 1 mM EDTA), and $0.02 \%$ RNase (Sigma) at $37^{\circ} \mathrm{C}$ for 30 minutes before hybridisation and used as a negative control.

\section{Results}

CRH $m R N A$ transcripts in ulcerative colitis

Recently, some studies have shown CRH mRNA in synovia from Lewis rats with adjutant induced arthritis and patients with rheumatoid arthritis. ${ }^{18} 19$ Using a similar reverse transcribed PCR method, we detected the segments of cDNA corresponding to specific CRH mRNA extracted from biopsy specimens from ulcerative colitis patients and normal subjects. Amplification of cDNA with $\mathrm{CRH}$ primers used in this study predicted a fragment of 425 base pair (bp) in length. All 10 ulcerative colitis patients and 10 normal subjects expressed CRH mRNA in colonic mucosa by PCR method. We could detect the same size bands for CRH mRNA. Figure 1 shows representative data of a normal subject (lane 1) and an ulcerative colitis patient (lane 2). Negative controls, performed with no RNA (lane 3) or no reverse transcriptase (lane 4), yielded no detectable bands. Primers specific for human $\beta$-actin generated the expected $541 \mathrm{bp}$ in all ulcerative colitis patients and normal subjects (data not shown).

\section{Immunohistochemistry}

Colonic biopsy specimens from normal subjects and ulcerative colitis patients were evaluated for immunoreactive CRH with affinity purified anti-CRH IgG. In normal colonic tissues, immunoreactive CRH expressed in a few mucosal epithelial cells and monocyte (Fig 2(C)). We found considerably enhanced expression of immunoreactive $\mathrm{CRH}$ in mucosal inflammatory cells in all ulcerative colitis patients, but not in the mucosal nerve fibres and the plexus (Fig 2(A)). Immunoreactive $\mathrm{CRH}$ of mucosal inflammatory cells was mainly distributed in mononuclear cells 


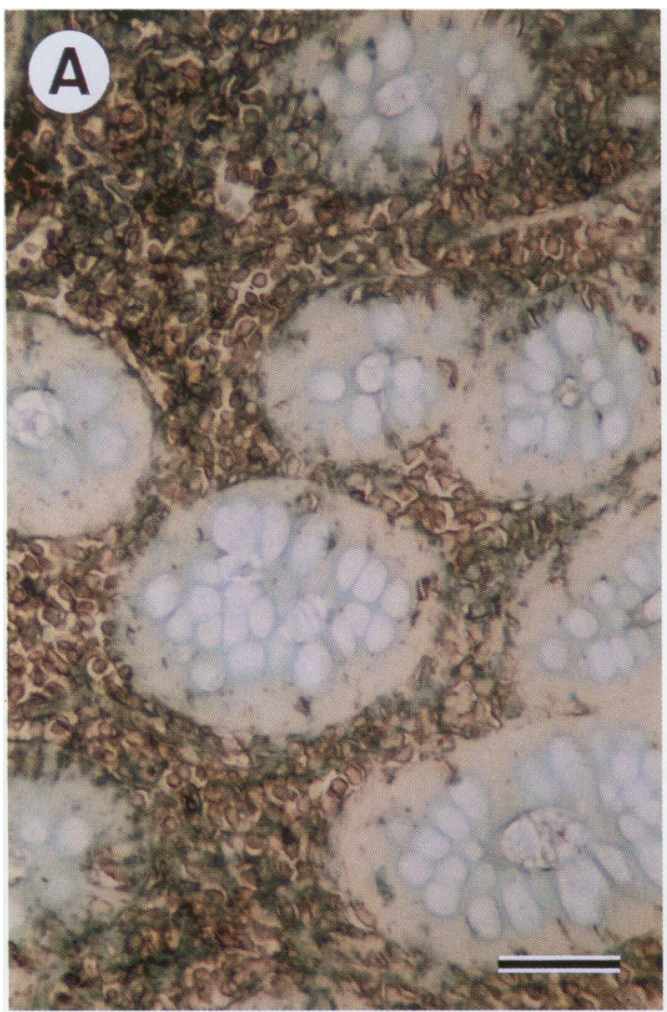

Fig $2 A$

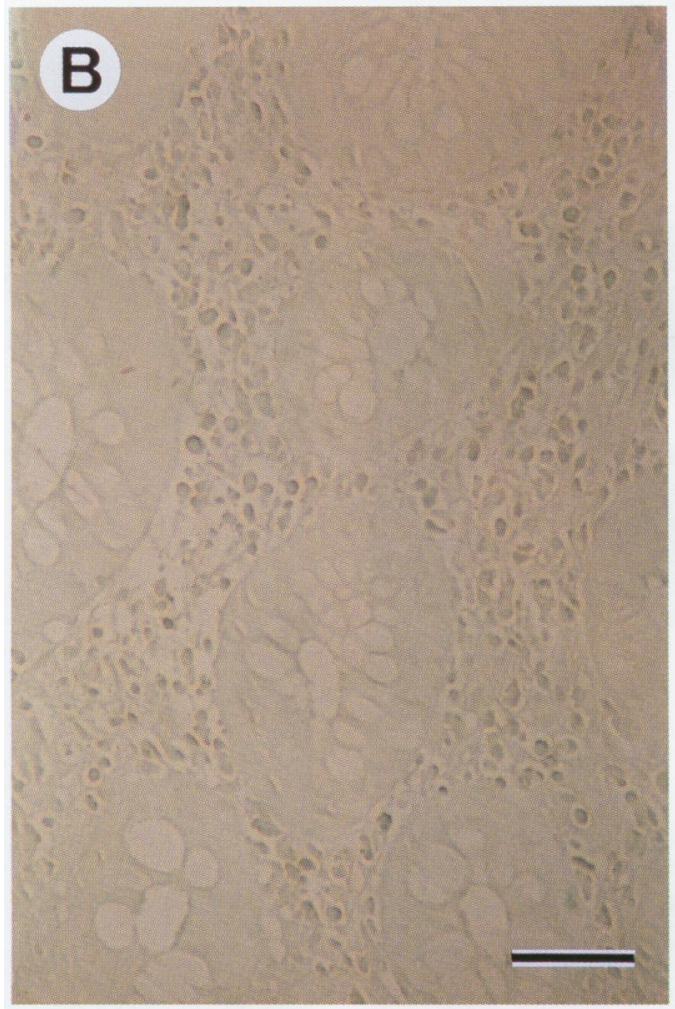

Fig $2 B$

including macrophages. Immunoreactive CRH expressed in colonic mucosal epithelial cells of ulcerative colitis was slightly, but not significantly, increased compared with that of normal colonic mucosal epithelial cells. Immunostaining with normal rabbit IgG was uniformly negative in all cases (Fig 2(B)).

Statistical analysis of CRH immunostaining

The extent and intensity of colonic tissues

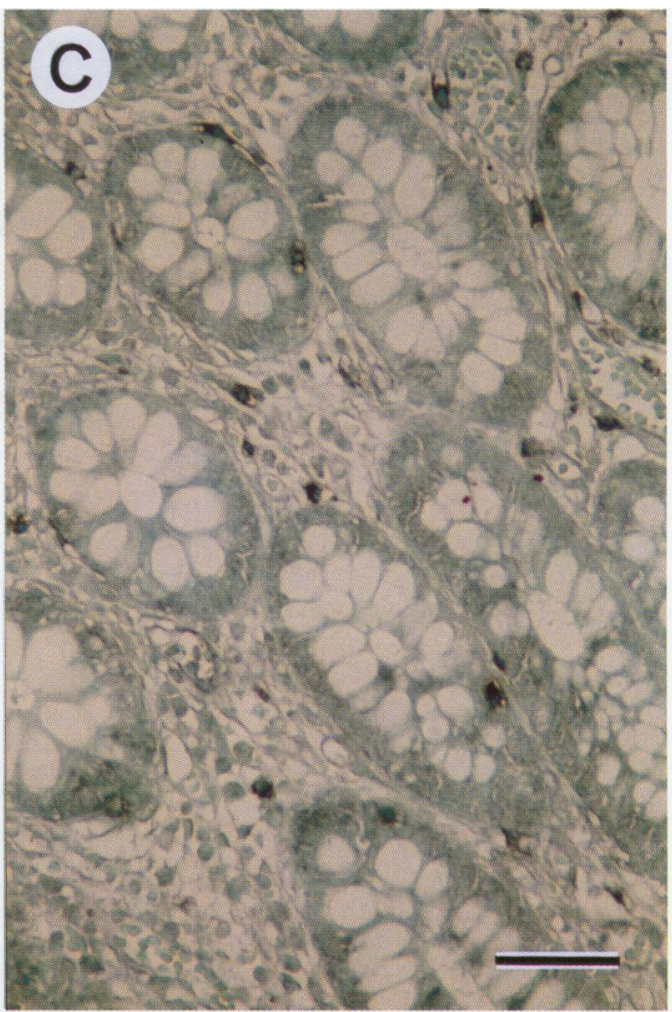

Fig $2 C$

Figure 2: Immunostaining for $\mathrm{CRH}$ in colonic mucosa from ulcerative colitis patients and normal subjects. Adjacent colonic tissue sections were stained with anti-CRH antibody $(A, C)$, or normal rabbit $\operatorname{Ig} G(B)$. Positive immunostaining $(A, C)$ was shown by brownish-black deposits and background was light green. Immunoreactive CRH localised to mucosal epithelial cells and mucosal inflammatory cells in patients with ulcerative colitis $(A)$, and in mucosal epithelial cells and mucosal monocytes in normal colonic mucosa (C). Control immunostaining with normal rabbit IgG was uniformly negative (B). (Bar $=100 \mu \mathrm{m}$.)

stained with anti-CRH antibody were graded 0 to $4+$ by two blinded observers on 10 ulcerative colitis patients, and 10 normal subjects. The extent and intensity of CRH immunostaining of mucosal inflammatory cells (Fig 3) from ulcerative colitis patients were significantly greater than normal subjects $(\mathrm{p}<0 \cdot 01)$.

\section{Double antibody immunostaining}

To identify the localisation of immunoreactive $\mathrm{CRH}$ in macrophages, we immunostained the same sections from the colonic biopsy specimens of ulcerative colitis by a double antibody staining method with antimacrophage antibody and anti-CRH antibody. Intense blackred deposits were detected in many mucosal inflammatory cells (Fig 4(A)). Control staining with normal rabbit IgG and BALB/C ascites fluid was uniformly negative (Fig 4 (B)). Staining with anti-CRH antibody/BALB/C ascites fluid showed only brownish-black deposits (data not shown). Staining with antimacrophage antibody/normal rabbit IgG showed only red deposits (Fig 4(C)). These findings suggested that many of the intense staining of CRH positive inflammatory cells in the colonic tissues of ulcerative colitis were mucosal macrophages. 


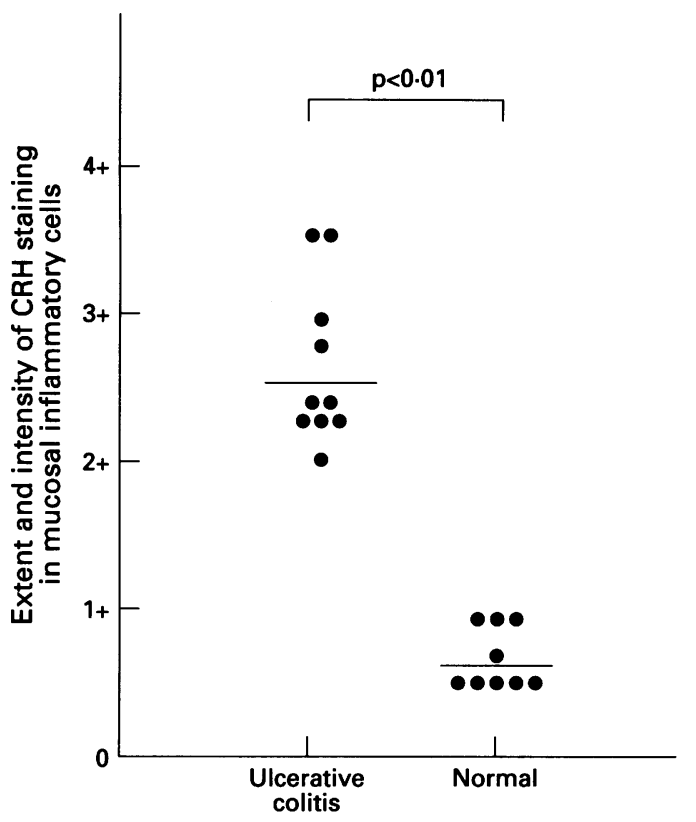

Figure 3: Statistical analysis of CRH immunostaining of colonic mucosal inflammatory cells from patients with ulcerative colitis. The extent and intensity of immunostaining with anti-CRH antibody in mucosal inflammatory cells of colonic tissues with normal subjects and ulcerative colitis patients were graded 0 to $4+$ by two blinded observers. CRH immunostaining was significantly more extensive and intensive in colonic tissues of ulcerative colitis patients $(n=10)$ than normal colonic tissues $(n=10)$ by Mann-Whitney U test $(p<0 \cdot 01)$.

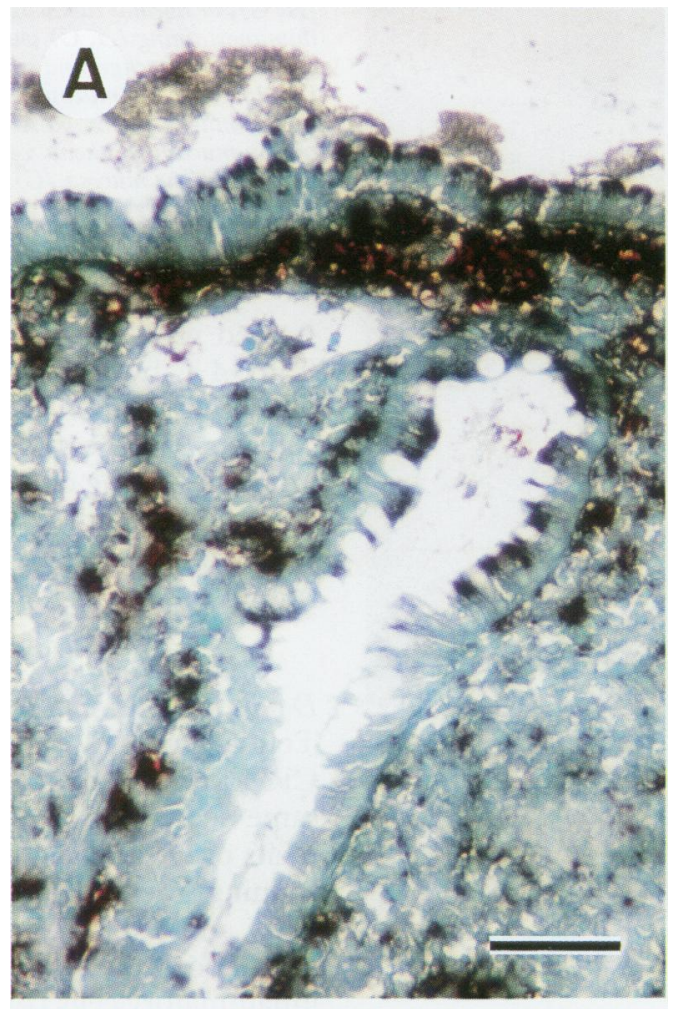

Fig $4 A$

Expression of CRH $m R N A$ in ulcerative colitis To examine the localisation of CRH mRNA in colonic tissues of ulcerative colitis patients and normal subjects, we performed in situ hybridisation with ${ }^{32} \mathrm{P}$-labelled oligonucleotide probe. In all biopsy specimens of ulcerative colitis patients (five of five), CRH mRNA was expressed in the colonic mucosal epithelial

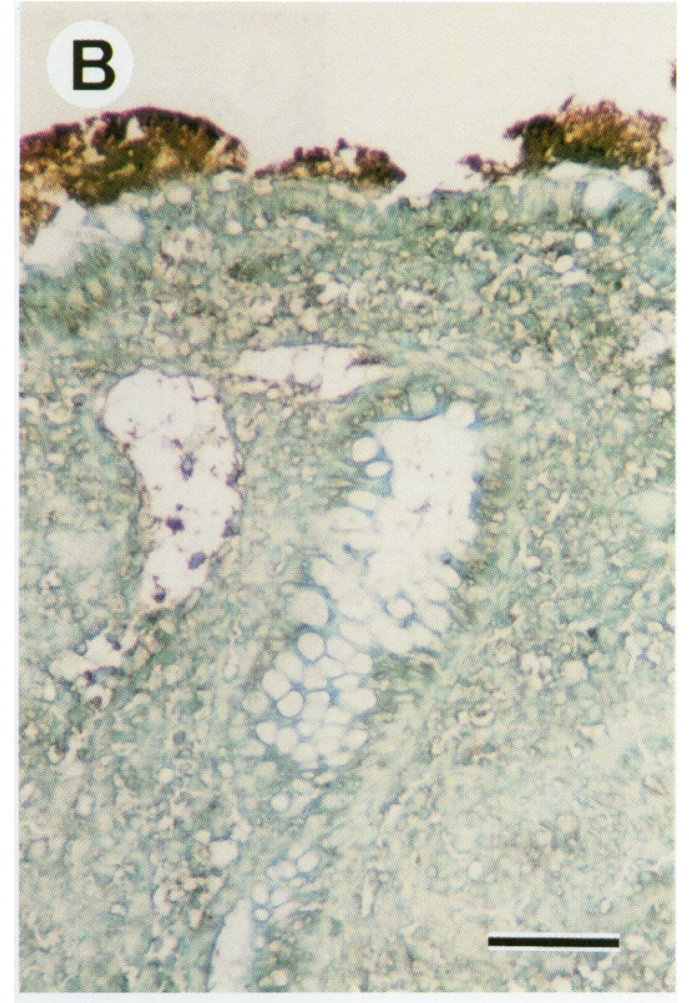

Fig $4 B$

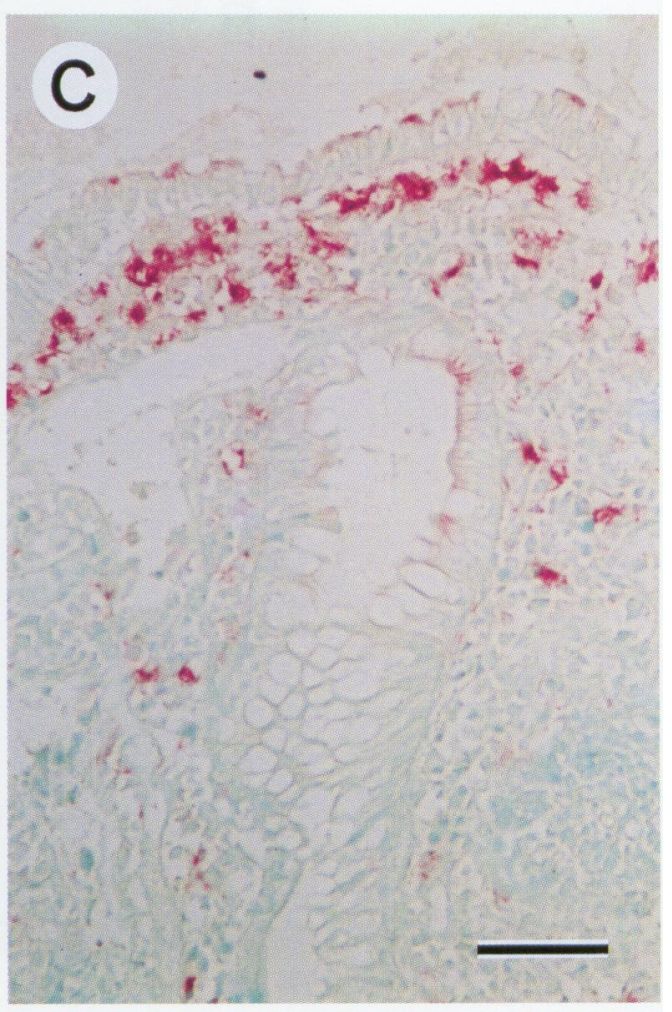

Fig $4 C$

Figure 4: Double antibody immunostaining with anti-CRH and antimacrophage antibody in same colon tissues of patients with ulcerative colitis. Sections were stained with antihuman pan-macrophage antibody using alkaline phosphatase method and anti-CRH antibody using peroxidase method $(A)$, and stained with antimacrophage antibody using alkaline phosphatase method and normal rabbit IgG using peroxidase method $(C)$. Counterstaining was done with $0.5 \%$ light green. Positive staining was shown by brownish-black deposits for the peroxidase method, red deposits for the alkaline phosphatase method, and black-red deposits for the double antibody staining. Control staining with normal rabbit IgG and BALB/C ascties fluid was uniformly negative (B). (Bar=200 $\mu \mathrm{m}$. 


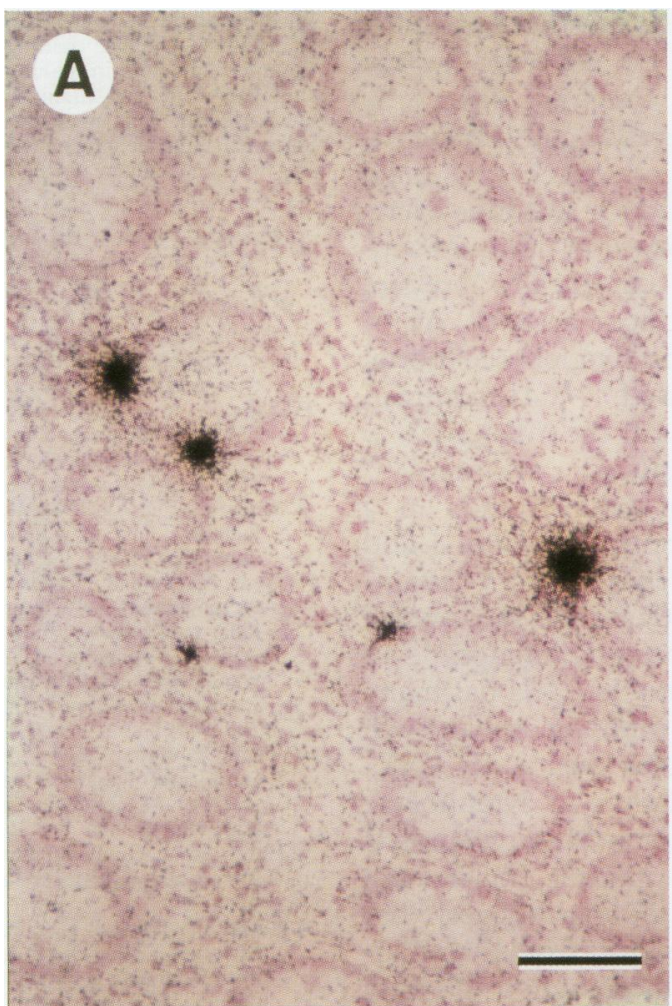

Fig $5 A$

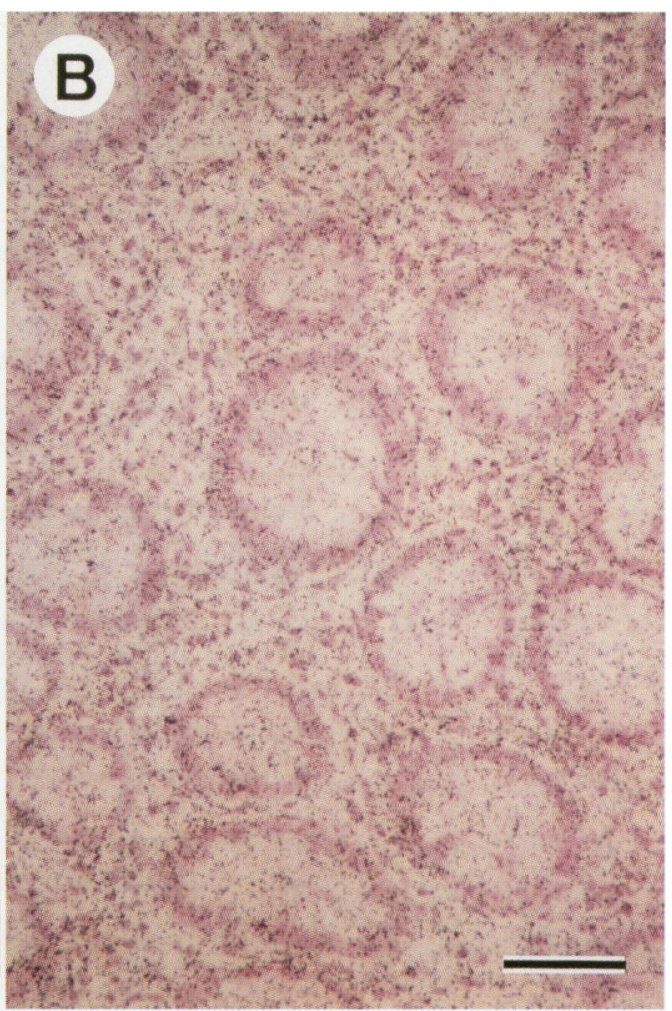

Fig $5 B$

Figure 5: In situ hybridisation for CRH $m R N A$ in colonic mucosa from patients with ulcerative colitis. CRH $m R N A$ in colonic mucosa in patients with ulcerative colitis was analysed by in situ hybridisation with ${ }^{32} P$-dCTP-labelled CRH oligonucleotide probe $(A)$. Counterstaining was done with haematoxylin. CRH mRNA was expressed in only mucosal epithelial cells. Negative control hybridisation incubated with RNase buffer showed only silver grains in background (B). (Bar=100 $\mu \mathrm{m}$.)

cells. CRH mRNA was localised to the mucosal layer. It was not detected in the submucosa, however, nor in the nerve fibres and plexus (Fig 5(A)). In all biopsy specimens of normal subjects (five of five), CRH mRNA was expressed in normal colonic mucosal epithelial cells (data not shown). It was difficult to compare inflamed mucosa with normal mucosa, because the structure of mucosa of ulcerative colitis was destroyed by inflammation and ulceration. In our study, the expression of CRH mRNA in mucosal epithelial cells of ulcerative colitis was not significantly increased compared with that of normal subjects. Negative control hybridisation incubated with RNase buffer showed only a few background silver grains (Fig 5(B)).

\section{Discussion}

We have shown that immunoreactive $\mathrm{CRH}$ expression was considerably increased in mucosal inflammatory cells in ulcerative colitis patients. The expression of immunoreactive CRH in colonic mucosal epithelial cells was slightly increased, but not significantly, compared with normal colonic mucosal epithelial cells including enterochromaffin cells. Double antibody immunostaining for $\mathrm{CRH}$ and macrophages antigen also showed that immunoreactive CRH was mainly expressed in mucosal macrophages. The extent and intensity of CRH immunostaining correlated with that of mononuclear cell infiltration in inflammatory colonic mucosa. This finding has been also shown in streptococcal cell wall and adjuvant induced arthritic joints in rats, ${ }^{19}$ and arthritic joints of patients with rheumatoid arthritis. ${ }^{20}$ The expression of CRH protein was abundant in colonic mucosal tissues from ulcerative colitis patients and correlated to the intensity of inflammation.

CRH mRNA is detectable by northern blot analysis of poly-A selected RNA from normal human peripheral blood lymphocytes. ${ }^{17} \mathrm{CRH}$ mRNA is also detected by the reverse transcribed PCR method in synovia from arthritic joints of rats and humans. ${ }^{1920}$ However, the source of CRH in inflammatory sites has been uncertain. We recently found that $\mathrm{CRH}$ was locally secreted by enterochromaffin cells in normal human colon. ${ }^{30}$ In this study, $\mathrm{CRH}$ mRNA was also detected in total RNA from ulcerative colitis colonic biopsy specimens by the reverse transcribed PCR method. Moreover, CRH mRNA was localised to colonic mucosal epithelial cells of patients with ulcerative colitis using in situ hybridisation. The expression of CRH mRNA in mucosal epithelial cells with ulcerative colitis was not significantly increased compared with normal colonic mucosal epithelial cells. We could not detect the CRH mRNA in inflammatory cells that strongly expressed immunoreactive CRH. This discrepancy might be explained by the stability of the mRNA or protein. One possibility is that CRH, which is abundant in inflammatory cells of ulcerative colitis, may be produced by the mucosal epithelial cells at an early stage of the onset of ulcerative colitis. At that time, CRH mRNA may be strongly expressed in mucosal epithelial cells such as enterochromaffin cells 
near the base of their crypts. Another possibility is that CRH may also be delivered to the inflammatory site of mucosal layer by mononuclear cells in ulcerative colitis patients.

Hypothalamic $\mathrm{CRH}$ influences peripheral glucocorticoids concentrations and thus exerts indirect anti-inflammatory and immunosuppressive effects. In the chronically stressful condition of adjuvant induced arthritis, hypothalamic CRH mRNA and hypophyseal portal venous $C R H$ are decreased. ${ }^{35-37}$ In contrast, peripheral CRH increases at the inflammatory sites of adjuvant induced arthritis. ${ }^{19} 20$ Immunoneutralisation of CRH results in a significant decrease on both the volume and cellularity of the carrageenin induced inflammatory exudate, suggesting that the overall effect of this peptide is proinflammatory. ${ }^{18}$ In vitro study has also shown that $\mathrm{CRH}$ has many regulatory effects on the immune system such as the secretion of cytokines such as IL-1, IL2 , and IL-6, ${ }^{13} 14$ stimulation of lymphocyte proliferation and expression of IL-2 receptor, ${ }^{15}$ and enhancement of natural killer cell mediated lysis. ${ }^{16}$ These findings suggest that peripheral CRH acts differently from hypothalamic CRH, modulating the function of many local immunoregulatory cells and the secretion/effects of a large array of inflammatory mediators. Increased production of IL-1 $\beta$ and IL- 6 by mononuclear cells isolated from the intestinal tissue of patients with ulcerative colitis and Crohn's disease has been reported. ${ }^{38-41}$ Peripheral $\mathrm{CRH}$ in inflamed colonic mucosa of ulcerative colitis patients may enhance the expression of such cytokines and stimulate the proliferation of lymphocytes, thereby, contributing to the inflammatory process.

Many gut neuropeptides, such as substance $P$ and vasoactive intestinal polypeptide, have been implicated in the pathogenesis of inflammatory bowel disease. ${ }^{23}$ For example, substance $P$ and its $\mathrm{mRNA}$ are expressed in the enteric nervous system throughout the gastrointestinal tract, and have immunomodulatory effects, including enhancement of lymphocyte and macrophage function..$^{24-27}$ In ulcerative colitis, substance $P$ is a potential neurogenic link between stimuli and inflammation of the intestinal tract. Immunoreactive $\mathrm{CRH}$ is found in sympathetic components of peripheral nervous system. ${ }^{42} 43$ In ulcerative colitis, we could find CRH and CRH mRNA in colonic epithelial and inflammatory cells, but not in the mucosal or submucosal nerve fibres and plexus. There is also the possibility as to whether peripheral $\mathrm{CRH}$ in colonic mucosa may be able to influence the mucosal nervous system in ulcerative colitis.

Thus, it is very tempting to implicate CRH as an important mediator in the pathogenesis of ulcerative colitis. The mechanism of actions of peripheral CRH are multiple and not completely elucidated, and the specific roles for CRH in the inflammatory response in ulcerative colitis remain to be solved. This study suggests that $\mathrm{CRH}$ in the colonic mucosa may act as a proinflammatory agent modulating the intestinal immune system.
We are grateful to Dr Leslie J Crofford for the gift of the primers of human CRH. We thank Ms Mari Hirose and Ms Yoshimi Watanabe for help in making tissue sections for immunohistochemistry and also thank Dr Mitsuhiro Kawata for in situ hybridisation. This work was supported by a grant in aid for hybridisation. This work was supported by a grant in aid for
Scientific Research from the Ministry of Education, Culture Scientific Research from the Minist
and Science of Japan (05807042).

1 Vale W, Spiess J, Rivier C, Rivier J. Characterization of a 41-residue ovine hypothalamic peptide that stimulates 1981; 213: 1394-7.

2 Sutton RE, Koob GF, LE Moal M, Rivier J, Vale W. Corticotropin-releasing factor produces behavioral activation in rats. Nature 1982; 297: 331-3.

3 Sahgal A, Wright C, Edwardson JA, Keith AB. Corticotropin-releasing factor is more potent than some corticotropin-related peptides in affecting passive avoidance behavior in rats. Neurosci Lett 1983; 36: 81-6.

4 Rivier C, Plotsky PM. Mediation by corticotropin releasing factor (CRF) of adenohypophysial hormone secretion. Annu Rev Physiol 1986; 48: 475-94.

5 Irwin M, Vale W, Rivier C. Central corticotropin-releasing factor mediates the suppressive effect of stress on natural factor mediates the suppressive effect of stress on nat
killer cytotoxicity. Endocrinology 1990; 126: 2837-44.

6 Dunn AJ, Berridge CW. Physiological and behavioral response to corticotropin releasing factor administration: is CRF a mediator of anxiety or stress response? Brain Res Rev 1990; 15: 71-100.

7 Tache Y, Goto Y, Gunion MW, Vale W, Rivier J, Brown M. Inhibition of gastric acid secretion in rats by intracerebral injection of corticotropin-releasing factor. Science 1983; 222: 935-7.

8 Bateman A, Singh A, Kral T, Solomon S. The immunehypothalamic-pituitary-adrenal axis. Endocr Rev 1989; 10: 92-112.

9 Suda T, Tomori N, Tozawa F, Mouri T, Demura H, Shizume $K$. Distribution and characterization of immunoreactive corticotropin-releasing factor in human tissues. F Clin Endocrinol Metab 1984; 59: 861-6.

10 Petrusz P, Mechenthlaler I, Maderdrut JL, Vigh S, Schally AV. Corticotropin-releasing factor (CRF)-like immunoreactivity in the vertebrate endocrine pancreas. Proc Natl Acad Sci USA 1983; 80: 1721-5.

11 Shibasaki T, Odagiri E, Shizume K, Ling N. Corticotropinreleasing factor-like activity in human placental extracts. $\mathcal{F}$ Clin Endocrinol Metab 1982; 55: 384-6.

12 Mastorakos G, Webster EL, Friedman TC, Chrousos GP. Immunoreactive corticotropin-releasing hormone and its binding site in rat ovary. $₹$ Clin Invest 1993; 92: 961-8.

13 Singh VK, Leu CSJ. Enhancing effect of corticotropinreleasing neurohormone on the production of interleukin 1 and interleukin-2. Neuroscience 1990; 120: 151-4.

14 Leu CSJ, Singh VK. Stimulation of interleukin-6 production by corticotropin-releasing factor. Cell Immunol 1992; 143: $220-7$.

15 Singh VK. Stimulatory effect of corticotropin-releasing neurohormone on human lymphocyte proliferative and interleukin-2 receptor expression. $\mathcal{F}$ Neuroimmunol 1989; 23: 257-62.

16 Leu CSJ, Singh VK. Modulation of natural killer cellmediated lysis by corticotropin-releasing hormone. $\mathcal{f}$ Neuroimmunol 1991; 33: 253-60.

17 Stephanou A, Jessop DS, Knight RA, Lightman SL. Corticotropin-releasing factor-like immunoreactivity and mRNA in human leukocytes. Brain Behav Immun 1990; 4: mRNA

18 Karalis K, Sano H, Redwine J, Listwak S, Wilder RL, Chrousos GP. Autocrine or paracrine inflammatory actions of corticotropin releasing hormone in vivo. Science 1991; 254: 421-3.

19 Crofford LJ, Sano H, Karalis K, Webster EL, Goldmuntz EA, Chrousos GP, et al. Local secretion of corticotropinreleasing hormone in the joints of Lewis rats with inflammatory arthritis. $\mathcal{f}$ Clin Invest 1992; 90: 2555-64.

20 Crofford LJ, Sano H, Karalis K, Friedman TC, Epps HR, Remmers EF, et al. Corticotropin-releasing hormone in synovial fluids and tissues of patients with rheumatoid synovial fluids and tissues of patients with rheumatoid
arthritis and osteoarthhritis. $\mathcal{F}$ Immunol 1993; 151: arthritis and

21 Bradin E, Sjouland K, Hakanson R, Sundler F. Substance Plike containing fibers are numerous in human but not in feline intestinal mucosa. Gastroenterology 1983; 85: 557-64.

22 Ferri Gl, Adrian TE, Ghatei MA, O'Shaugnessy DJ, Probert L, Lee YC, et al. Tissue localization and relative distribution of regulatory peptides in separated layers from human bowel. Gastroenterology 1983; 84: 777-86.

23 Koch TR, Carney JA, Go VLW. Distribution and quantitation of gut neuropeptides in normal intestine and inflamtion of gut neuropeptides in normal intestine and inflam

24 MacFadden D, Zimmer MJ, Jaffe BM. Substance Pinduced intestinal secretion of water and electrocytes. Gut induced intestinal sec.

25 Silkof P, Karmeli F, Goldin E, Ewenson A, Gilon C, Chorev $M$, et al. Effect of substance $P$ in rat gastrointestinal transit. Dig Dis Sci 1988; 33: 74-7.

26 Konturek SJ, Jaworek J, Tasler J, Cieszdowski M, Pawlik W. Effect of substance $P$ and its $C$-terminal hexapeptide on gastric and pancreatic secretion in dog. Am $\mathcal{F}$ Physiol 1985; 214: G74-81.

27 Jonakait GM, Schotland S, Hart RP. Effect of lymphokine on substance $P$ in injured ganglia of the peripheral nervous system. Ann NY Acad Sci 1991; 632: 19-30. 
28 McGuigan JE. Hormones of gastrointestinal tract. In: DeGroot LJ, Besser GM, Cahill GF, eds. Endocrinology. DeGroot LJ, Besser GM, Cahill GF, eds. End

29 O'Dorisio MS, Wood CL, D'Dorisio TM. Vasoactive intestinal peptide and neuropeptide modulation of the immune response. F Immunol 1985; 135: 7925-65.

30 Kawahito Y, Sano H, Kawata M, Yuri K, Mukai S, Yamamura $\mathrm{Y}$, et al. Local secretion of corticotropin releasing factor by enterochromaffin cells in human colon. Gastroenterology 1994; 106: 859-65.

31 Chomczynski P, Sacchi N. Single step method of RNA isolation by acid guanidinium thiocyanate-phenol-chloroform extraction. Anal Biochem 1987; 162: 156-9.

32 Radzum HJ, Parwaresch MR, Feller AC, Hansmann M-L. Monocyte/macrophage-specific monoclonal antibody $\mathrm{Ki}-$ Monocyte/macrophage-specific monoclonal antibody Ki1985; 117: 441-50.

33 Sano H, Engleka K, Mathern P, Hla T, Crofford LJ, Remmers EF, et al. Coexpression of phosphotyrosinecontaining protein, platelet-derived growth factor-B, and fibroblast growth factor-1 in situ in synovial tissues of patients with rheumatoid arthritis and Lewis rats with adjuvant or streptococcal cell wall arthritis. $\mathcal{f}$ Clin Invest 1993; 91: 553-65.

34 Vamvakopoulos NC, Karl M, Mayol V, Gomez T, Stratakis CA, Margioris A, et al. Structural analysis of the regulatory region of the human corticotropin releasing hormone tory region of the human corticotropin releasing hor.

35 Harbuz MS, Rees RG, Eckland D, Jessop DS, Brewerton D, Lightman SL. Paradoxical responses of hypothalamic corticotropin-releasing factor (CRF) messenger ribonucleic acid (mRNA) and CRF-41 peptide and adreno- hypophysical proopiomelanocortin mRNA during chronic inflammatory stress. Endocrinology 1991; 130: 1394-400.

36 Lightman SL, Young III WS. Influence of the steroids on the hypothalamic corticotropin-releasing factor and preproenkephalin mRNA responses to stress. Proc Natl Acad Sci USA 1989; 86: 4306-10.

37 Frim DM, Robinson BG, Pasieka KB, Majzoub JA Differential regulation of corticotropin-releasing hormone mRNA in rat brain. Am F Physiol 1990; 258: E686-92.

38 Sartor RB, Champman EJ, Schwab JH. Increased interleukin $1-\beta$ concentrations in resected inflammatory bowel disease (IBD) tissue Gastroenterology 1988; 94: 309-14.

39 Mahida YR Wu K, Jewell DP. Enhanced prod interleukin $1-\beta$ by mononuclear cells prolated from mucosa of active ulcerative colitis and Crohn's disease.

40 Mitsuyama K, Sata M, Tarikawa K. Significance of interleukin 6 in patients with inflammatory bowel disease. Gastroenterol fpn 1991; 26: 20-8.

41 Kim L, Isaacs R, Balfour S, Haskill S. Cytokine messenger RNA profiles in inflammatory bowel disease mucosa detected by polymerase chain amplification Gastroenterology 1992; 103: 1587-95.

42 Skofitsh G, Hamil GS, Jacobowitz DM. Capsaicin depletes corticotrophin-releasing factor-like immunoreactive neurons in the medulla oblongata and spinal cord. Neuroendocrinology 1984; 38: 514-7.

43 Merchenthalar I, Hynes MA, Vingh A, Schally V, Petrusz P. Immunocytochemical localization of corticotropin-releasing factor (CRF) in the rat spinal cord. Brain Res 1983; 275: 373-7. 